\title{
Ethno-philosophy is Rational: A Reply to Two Famous Critics
}

\author{
Fainos Mangena \\ Department of Religious Studies, Classics and Philosophy \\ University of Zimbabwe, Zimbabwe \\ Fainosmangena@gmail.com \\ DOI: http://dx.doi.org/10.4314/tp.v6i2.3
}

Thought and Practice: A Journal of the Philosophical Association of Kenya (PAK)

New Series, Vol.6 No.2, December 2014, pp.23-38

thoughtandpractice@gmail.com

http://ajol.info/index.php/tp/index

ISSN: 2076-7714 


\begin{abstract}
In this article, I contend that philosophical reactions against ethno-philosophy, especially the arguments by professional African philosophers such as Paulin Hountondji and Kwame Anthony Appiah, cannot go unchallenged at a time when Africa is facing a myriad of problems such as disease, famine, ethnic conflicts, religious wars, and natural disasters which, in my view, stem from the continent's failure to reflect on its past in the quest for lasting solutions. Having looked at the historical context of the emergence of ethno-philosophy or the project of cultural revivalism, and having closely examined the premises presented by Hountondji and Appiah against ethno-philosophy - which I consider to be unconvincing because of their tendency to glide into Western philosophical forms of thought - I argue that ethno-philosophy is just like Western philosophy, as it is based on a recognized form of reasoning, namely inductive reasoning, which is packaged in proverbs, riddles and other cultural resources. I also argue that religious beliefs are not an obstacle to the development of scientific thought in Africa; rather, they are an aid to it since both have complementary rather than opposing roles.
\end{abstract}

\title{
Keywords
}

Philosophy, ethno-philosophy, primitive unanimity, induction, African proverbs

\section{Introduction}

As a regular contributor in the area of African philosophy, particularly on its attendant concept hunhu/ubuntu, I have had to face hard questions from colleagues at work and those I have met at international conferences who have accused me and others that have contributed in this area of being too simplistic or overly ambitious in defending this system of thought as a distinct category of African philosophy. While in the past I have argued for the recognition of hunhu/ubuntu philosophy in Zimbabwe, in this article I appeal to a different form of argument in order to defend ethno-philosophy against what I consider to be an unjustified attack by professional African philosophers. ${ }^{1}$ I attempt to make a case for ethno-philosophy, showing that it is a philosophy based on reason and evidence just like Western philosophy.

\footnotetext{
${ }^{1}$ Professional African Philosophers are identified not only by their credentials as doctors of philosophy from Western universities or Western style universities in Africa, but also by a common conviction among them that philosophy, in its strictest academic sense, is a universal mode of inquiry. The sort of investigation that Professional African Philosophers engage in is often described as a "second order activity" on first order claims to truth about the
} 
Recently, as I was carrying out research on ethno-philosophy, I came across a very interesting article by Jay A. Ciaffa titled "Tradition and Modernity in Postcolonial African Philosophy" (Ciaffa 2008) which revisited this debate, focusing on the contributions of Hountondji, Appiah and Gyekye in their critique of ethno-philosophy. My discovery of this article stimulated my interest in replying to those who have charged ethno-philosophy of being uncritical and irrational. In my reply to such critics, I do three things:

(1) Outline familiar objections to ethno-philosophy.

(2) Offer a critique of these objections.

(3) Show why ethno-philosophy is a project that is worth pursuing in light of the many problems bedeviling Africa today, which, in my view, are due to the failure of Africa to harness its philosophy in order to solve them.

Among the Shona ${ }^{2}$ of Zimbabwe, there is a proverb which says: Chimwango choumwe hachina ndima (A borrowed hoe cannot cover enough ground). This proverb can be used to succinctly express the fact that Western philosophies and sciences cannot wholly solve Africa's problems.

\section{Ethno-philosophy: A Definition}

Since ethno-philosophy is an aspect of African philosophy, it is important to begin this article by defining African philosophy. To this end, K.C. Anyanwu and E.A. Ruch (1981) define African philosophy as "that which concerns itself with the way in which African people of the past and present make sense of their destiny and of the world in which they live." Understood this way, African philosophy becomes that kind of philosophy which must necessarily be produced by African people and must use distinct African philosophical methods (Janz 2009, 75-76).

Imbo (1998, 38-39) notes that although African philosophers are found in the various academic fields of philosophy such as metaphysics, epistemology, moral philosophy and political philosophy, much of the modern African philosophy has been concerned with defining ethnophilosophy as an aspect of African philosophy and identifying what differentiates it from other philosophical traditions. In this article, I focus more on the criticisms leveled against ethno-

world, knowledge, inference and values. As a second order activity, so they claim, philosophy evaluates first order claims in order to clarify their meanings and to identify appropriate ways of justifying them. It essentially involves reflection, criticism, argument and written peer review (English and Kalumba 1996, 7).

\footnotetext{
${ }^{2}$ The Shona people constitute the largest linguistic grouping in Zimbabwe which is made up of six dialects, namely, Karanga, Korekore, Zezuru, Ndau, Manyika and Kalanga.
} 
philosophy by professional African philosophers. Before I do this, I define ethno-philosophy. To this end, I begin by reviewing the definition by Imbo (1998, 38-39) who provides a somewhat general definition of the idea as "the study of indigenous philosophical systems". In defining ethno-philosophy this way, no doubt, Imbo is of the view that specific cultures can have philosophies that are not applicable and accessible to all peoples and cultures in the world (Imbo 1998, 38-39).

Most professional African philosophers have defined ethno-philosophy as the recollection or recording of the beliefs found in African cultures (Proteus 2007). Such an approach treats African philosophy as consisting in a set of shared beliefs, a shared world-view, an item of communal property rather than an activity for the individual (Proteus 2007).

Zeverin Emagalit (2006) falls into the category of African philosophers that see ethnophilosophy as a (re)collection of oral wisdom. For Emagalit, ethno-philosophy is a system of thought that deals with collective world views of diverse African people as a unified form of knowledge based on the myths, folk wisdom and proverbs of the people:

Ethno-philosophy is, ..., a specialized and wholly customs dictated philosophy that requires a communal consensus. It identifies with the totality of customs and common beliefs of a people. It is a folk philosophy (Emagalit 2006).

This is the kind of position that I challenge in this article. In my view, ethno-philosophy entails two tasks, namely, the collection and analysis of indigenous African thought systems. I will explain the second task in the last section of this article as I offer a critique of the arguments by professional African philosophers. In the next section, I look at the historical context of ethnophilosophy, with a view to showing that ethno-philosophy is a philosophy about Africa's quest for identity, so that it cannot simply be a collection of indigenous African beliefs, norms, values and customs which Appiah and company have called oral folk philosophy.

\section{The Historical Context of Ethno-philosophy}

As Ciaffa $(2008,123)$ observes, "ethno-philosophy has its historical roots in the colonial era, in fact it emerged as a response to the European discourse about African culture and identity." Ciaffa maintains that in order to understand the cultural revivalist project, it is necessary to begin with some brief remarks on this European discourse (Ciaffa 2008, 124). He begins his account by noting that colonialism in Africa was supported by a broad range of popular and scholarly literature which highlighted fundamental differences between Europeans and Africans (Ciaffa 2008, 124). 
One of the most notorious examples of this literature was the work of the French Anthropologist, Lucien Levy-Bruhl, who distinguished between the alleged mentality of the civilized Europeans and that of the primitive non-Europeans by arguing that the primitive mentality was pre-logical (cited in Offia 2009). Levy-Bruhl described a "pre-logical thought" as one that was unscientific, uncritical and containing evident contradictions (cited in Oyeshile 2008, 57). Just like LevyBruhl, G.W.F. Hegel (1956) did not believe that Africans could philosophize and that there was something called African philosophy that was worth celebrating.

Reacting to these Western philosophers, particularly Levy-Bruhl's attack on the black African, Ciaffa noted that the images of the civilized European and primitive African helped sustain the idea that colonialism was a fundamentally benevolent enterprise, that is, a venture in which Europeans were attempting to bring civilization to the "dark continent" (Ciaffa 2008, 124). As Ciaffa notes, it was important for African philosophers to explore and revitalize traditional African thought as a basis for their struggle against colonialism (Ciaffa 2008, 125). This is what inspired African philosophers - especially ethno-philosophers - to write about the need for cultural revivalism. Placide Tempels' Bantu philosophy provided a template for this noble project. This is despite the fact that Tempels' study of the Bantu people of Congo had been viewed as having colonial motives - to facilitate conversion to Christianity. Tempels' work challenged prevailing ideas about the primitive mind as earlier on promulgated by Levy-Bruhl and others (Ciaffa 2008, 125).

Leopold Senghor was among the pioneers of the project of ethno-philosophy through his celebrated philosophy of negritude. In apparent reference to the black African, he argued that the Negro was a man of nature and was more sensuous and responsive to the rhythms of the environment than his white counterpart (Senghor 1995). Senghor has this to say about the European's attitude to nature:

Whites approached the environment in the manner of a scientist or an engineer differentiating themselves from the natural world, placing nature at a distance, so to speak. Through this objective stance, the natural world can be surveyed, measured and, ultimately, manipulated for human purposes (Senghor 1995).

Senghor also directly challenged claims of white superiority in his philosophy of negritude as he observed that Africans were equal to Europeans. In fact, he objected to the view widely held in the West that the Negro lacked reason by arguing that the Negro had a different form of reasoning and a different way of understanding the world (Senghor 1995). For Ciaffa, the goal of Senghor and other ethno-philosophers is to mobilize African cultural norms to address contemporary problems (Ciaffa 2008, 126). 


\section{Philosophical reactions to Ethno-philosophy}

In this section I look at the reactions of professional African Philosophers to the project of ethnophilosophy. In particular, I examine the reactions of two famous professional African Philosophers, namely, Paulin J. Hountondji and Kwame Antony Appiah. These two also belong to the universalist camp which opposes the Particularist camp's assertion that philosophy is culture-specific.

\section{Hountondji's submissions}

Hountondji is without doubt one of the fiercest critics of ethno-philosophy. He begins his critique by noting that African philosophy exists by the same right and in the same mode as all the philosophies of the world: in the form of literature whereby African scholars simply make use of African traditions and orality and project onto them their own philosophical beliefs (Hountondji 1996, 62). Hountondji (1996, 33) observes: "By African philosophy, I mean a set of texts, specifically the set of texts written by Africans and described as philosophical by their authors themselves." By this claim, he is suggesting that African Philosophy cannot exist as a distinct category of philosophy; instead it is a creation of those Africans who use their intellectual powers to see philosophy where there is no philosophy by regarding traditions as philosophy.

By arguing that African philosophy cannot exist as a distinct category, Hountondji is particularly reacting to Placide Tempels, who, through his coinage of the phrase Bantu Philosophy, had asserted that Africans had a distinct philosophy and Alexis Kagame's Bantu-Rwandais Philosophy which had focused on the philosophy of the Rwandese people. As a reaction to these claims, Hountondji $(1996,62)$ remarks that "both Tempels and Kagame simply make use of African traditions and oral literature and project onto them their own philosophical beliefs, hoping to enhance their credibility thereby."

For Hountondji, the existence (or lack thereof) of African philosophy depends entirely on whether the word philosophy when qualified by the word African retains its habitual meaning, or whether the simple addition of an adjective necessarily changes the meaning of the substantive (Hountondji 1996, 56). For Hountondji, what is in question then is the universality of the word philosophy throughout its possible geographical locations (Hountondji 1996, 56). He writes:

This universality must be preserved - not because philosophy must necessarily develop the same themes or even ask the same questions from one country or continent to another, but because these differences of content which, as such, 
refer back to the essential unity of a single discipline, of a single style of enquiry (Hountondji 1996, 56).

Hountondji also challenges what he calls the "myth of primitive unanimity". For him, ethnophilosophy gives the false impression that in "primitive" societies, that is, non-Western societies, people are united on those fundamental issues that define their existence, and there are no individual beliefs or philosophies but only a collective system of beliefs (Hountondji 1996, 60). For him, the term philosophy is then incorrectly used to refer to such belief systems (Hountondji 1996, 60). This unity, for Hountondji, is imaginary, as ethno-philosophers want to interpret a text which nowhere exists and has to be constantly re-invented; they claim to have a science without an object and a discourse that has no referent, so that its falsity can never be demonstrated (Hountondji 1996, 62).

Thus Hountondji's understanding of ethno-philosophy is that of a study devoid of any meaningful philosophy. As earlier observed, this argument is based on his universalist understanding of the meaning of the word philosophy as a discipline that is methodical, rational and critical. Against this background, Hountondji remarks:

While they were looking for philosophy in a place where it could never be found - in the collective unconscious of African peoples, in the silent folds of their explicit discourse - ethno-philosophers never questioned the nature and theoretical status of their own analyses (Hountondji 1996, 62).

Hountondji also thinks that "ethno-philosophy is a pre-philosophy mistaking itself for a metaphilosophy, ${ }^{3}$ a philosophy which, instead of presenting its own rational justification, shelters lazily behind the authority of tradition and projects its own theses and beliefs onto that tradition" (Hountondji 1996, 63).

\section{Appiah's position}

In his contribution to the ethno-philosophy debate, in particular the argument on African unanimity of thought earlier questioned by Hountondji, Appiah $(1992,26)$ argues that whatever Africans share, they do not have a common traditional culture, common language, or a common religious and conceptual vocabulary. In fact, as Appiah puts it, "Africans share too many problems to be distracted by a bogus basis for solidarity" (Appiah 1992, 26).

\footnotetext{
${ }^{3}$ Meta-philosophy, for Hountondji, means that philosophy can develop only by reflecting on its history. It also means that all new thinkers must be fed on the doctrines of their predecessors... so as to enrich the historical heritage available in their own time (1996: 63).
} 


\section{Fainos Mangena}

Appiah thinks that the absence of unanimity of thought in Africa necessarily weakens arguments for the project of ethno-philosophy. The question is: How? In response to this question, Appiah argues that unanimity of thought undergirds the project of ethno-philosophy, so that any attack on such unanimity is also an attack on the project of ethno-philosophy (Appiah 1992, 95). Note that Appiah does not question the existence of folk philosophy in Africa. In fact, he makes the following affirmation in regard to the existence of oral folk philosophy in Africa:

The sense in which there is a philosophical tradition in Africa is...that there is an oral folk philosophy whose authority lies largely in its purported antiquity, not the quality of the reasoning - or evidence - that sustains it, and which is usually unable to treat critical activity as disinterested (Appiah 1992, 91).

Just like Hountondji, Appiah's contention is not that no form of philosophy exists in Africa; his problem is the suggestion that ethno-philosophy has the same status as Western philosophy. This, to him, would give the impression that Africans can philosophize the same way as Western philosophers. Yet he acknowledges [above] that the hallmark of Western philosophy is the use of reason and evidence, two aspects that are glaringly absent in oral folk philosophy - at least according to him. For Appiah, the designation African philosophy seems to give the impression that traditions, customs, norms, beliefs and values in Africa are homogenous. Against this background, he writes:

If 'Africa' in 'African philosophy' is meant to distinguish a natural kind, there seems no terribly good reason for supposing that the answer should be yes. Why should the Zulu, the Azande, the Hausa and the Asante have the same concepts or the same beliefs about those matters which the concepts are used to think about and discuss? It seems they do not. If similarities are expected, it should be on the basis of the similarities between economies and social structures of traditional society (Appiah 1992, 91).

Appiah maintains that "many traditional African societies have as much in common with traditional societies that are not African as they do with each other, so that there is no reason to think that the folk philosophies of Africa are uniform" (Appiah 1992, 92). For Appiah, ethnophilosophy is only a useful beginning. Why does Appiah take this position? One way to answer this question would probably be to say that he is influenced by the position of his contemporaries. In fact, Appiah cites Kwasi Wiredu (1980) and Marcien Towa (1971) who also mount a full scale attack on ethno-philosophy. He presents Wiredu as having argued that "there is no philosophical interest in a recovery and preservation of traditional ideas that is not critical" (Wiredu cited in Appiah 1992, 92). He also presents Towa as having argued that "the mere accumulation of traditions is a diversion from engagement with the real political issues facing Africa, issues her philosophers ought to articulate and address" (Towa cited in Appiah 1992, 92). It is critical to note that although Appiah does not explicitly refer to ethno-philosophy as oral 
folk philosophy, his intuition is that ethno-philosophy is not based on reason and evidence - two critical aspects that define Western philosophy. My reason for reaching such a conclusion has to do with the claim he makes that "there is no possibility of not bringing a Western philosophical training to bear. What we must be careful of is simply projecting Western ideas, along with Western-derived methods, into the indigenous conceptual framework" (Appiah 1992, 92). His point is that African philosophy cannot be a stand-alone category of philosophy that can compete at the level of other philosophies of the world such as British philosophy, American philosophy and Greek philosophy.

\section{Critical Remarks}

Having outlined the historical context of ethno-philosophy and the reactions to it by two professional African philosophers in the previous two sections, in this section I examine what I consider to be some of the shortcomings of these arguments.

From the outline in the previous two sections, it would seem that professional African philosophers have problems in elevating ethno-philosophy to the same level as British philosophy, American philosophy and Greek philosophy to name just a few of the world's celebrated philosophies. Although they acknowledge that it is some form of philosophy, they are quick to point out that it operates at the lowest level since it lacks the elements of reason and a distinct method. In short, they assert that it lacks the critical component required of any genuine philosophy.

To Hountondji and Appiah, ethno-philosophy is only a recollection of beliefs, customs, values and aspirations of a particular group of people. For them, philosophy is the same throughout the world, using the same methods and asking the same questions (cf. Hountondji 1996, 56 and Appiah 1992, 91-92). The other point they make is that the designation African philosophy is problematic given the diversity of African cultures and traditions. To them, what is sensible is to talk of oral folk philosophies of these cultures (cf. Hountondji 1996, 62).

Beginning with the first line of argument presented by these two professional philosophers - the view that ethno-philosophy is a collection of beliefs, customs, values and aspirations of a particular group of people and lacks the critical component required of any genuine philosophy, it would seem to me that for these philosophers, a philosophy can only be genuine if it can go beyond a mere collection of beliefs, customs, values and aspirations of a certain group of people. While I agree with this submission, I do not quite agree with the position that this applies to ethno-philosophy. In my view, ethno-philosophy is not a mere collection of beliefs, customs, values and traditions of a particular group of people; it also involves critical analysis of the 
same. Reasoning involves analyzing the relationships between or among given premises and drawing conclusions from them. Thus reasoning - as an analytical task - is a product of two mental processes, namely, deduction and induction. In the deductive process, the conclusion which is drawn from given premises follows with necessity, while in the inductive process the conclusion follows with probability. It is unfortunate that most definitions of ethno-philosophy, especially by professional philosophers, have tended to focus on the 'collection' task, thereby deliberately ignoring the 'analysis' task.

Let me say a little bit more about this 'analysis' task of ethno-philosophy. Some people might ask: How is it possible that ethno-philosophy can be analytical? If one attempts to understand the concept of 'analysis' from the perspective of Western thinking which is by and large deductive, then there might be a problem. However, if one attempts to understand the same concept in an African context, which is by and large inductive, there would not be any problem. I will try to make my point clear by explaining what 'understanding African concepts from an inductive point of view' means, and then I will employ African proverbs ${ }^{4}$ as illustrations. A piece of inductive reasoning obtains when the arguer merely tries to establish the probability of a conclusion from given premises. In such an instance, the premises are intended only to be so strong that, if they were true, then it would be unlikely that the conclusion would be false (Groarke 2014). Thus the key assumption that governs inductive reasoning is that known cases can provide information about unknown cases (Gwaravanda and Masaka 2008, 197). For example, if one says that:

In 2012, about 50 prostitutes died of HIV and AIDS related complications at Siboza growth point in Zvishavane.

in 2013, about 62 prostitutes died of HIV and AIDS related complications at Siboza growth point in Zvishavane.

The person can be justified to conclude that about 70 prostitutes are likely to die of HIV and AIDS related complications at Siboza growth point in Zvishavane in 2014.

Please note that in inductive reasoning, the conclusion follows with probability. Thus while the two premises above show the trend of prostitutes dying of HIV and AIDS related complications in the years 2013 to 2014 and the probability that the number of prostitutes dying of HIV and AIDS complications is likely to increase slightly in the year to follow, the trend may change if

\footnotetext{
${ }^{4}$ I am aware that an attempt has been made by some of these professional African philosophers to recommend the use of proverbs to move ethno-philosophy to what they call the second order sense of knowledge which is rational, but I go beyond this recommendation to do the actual analysis of the same. I believe it is one thing to make a recommendation, and quite another to implement the recommendation.
} 
there are interventions, say, in the provision of Anti-retroviral therapy or behavior change. Whatever the case, the conclusion drawn from these premises follows with probability.

Another example could be:

In Zimbabwe, it has rained in November every year for the past four years.

Therefore, it will rain in Zimbabwe this coming November.

Again, it is important to see how the arguer is drawing his or her conclusion from the premises. After having carefully observed the patterns of rainfall in Zimbabwe over the past four years and having noted that rains usually come in November, the conclusion follows with probability that it will rain again this coming November. However, due to climate change, the rains may fall before or after November. Nevertheless, a conclusion can be drawn from the provided premises that is probably true.

Let us now consider the issue of African proverbs as illustrations of inductive reasoning. If it was difficult, in the first generation of Shona society, to have a person who could live successfully without listening to other people's advice or without seeking help from others, and if there were such difficulties again in the second and third generations of Shona society, then one could be justified to argue that even in the present generation the Shona proverb, rume rimwe harikombi churu (one man cannot surround an anthill) still applies, and it refers to the difficulties a person can encounter if he or she does not seek help or advice from other people in order to accomplish an important task. No doubt, this kind of conclusion is reached inductively, that is, after a rigorous analysis of the situation as it obtained in the first generation of Shona society. The job of the ethno-philosopher, then, would be to collect and analyze these proverbs to see if philosophical thinking can be mined from them.

Another instance of inductive reasoning is seen in the conceptualization of the proverb: Paduku paduku hapadzokwi (It does not matter how small the area covered is in completing a task, that small area will never be repeated). This points to the fact that the accomplishment of a big task is a step by step process, and that a preceding step will never be repeated and yet it will contribute to the completion of the task. Note that proverbs are not only characteristic of the nature of ethno-philosophy among the Shona of Zimbabwe: they are to be found across the breadth and width of black Africa.

E.A Alagoa of Nigeria (cited in King 2007, 3) argues that the existence of an African philosophy of history stems from traditional proverbs, and that age is an important factor in gaining wisdom and interpreting the past. To illustrate this point, he cites the proverbs: "More days, more 
wisdom" and "what an old man sees while seated, a youth does not see standing" (Cited in King 2007, 3). No doubt, these proverbs are used to show the veritable nature of ethno-philosophy. Just like Shona proverbs, these Nigerian proverbs are an outcome of a rigorous process of analysis of past events and how they have had an impact on the present, and how they are likely to have an impact on the future. Reason is crucial in this process of analysis. Against this background, it will be misleading for Professional African philosophers to suggest that ethnophilosophy is not based on reason.

Gwaravanda and Masaka (2008, 197) make use of the Shona word Zvirahwe (riddles) to illustrate that ethno-philosophy is based on inductive reasoning. For them, the type of inductive reasoning used in Shona riddles is the argument from analogy which is defined by Horner and Westacott $(2000,66)$ as a similarity between two things or situations. An example of an analogy is comparing mbeu (seed) germinating from the soil and mwana (baby) coming out of its mother's womb, noting the points of similarity and difference. Thus a person could come up with the following expression referring to his or her child who is born without any deformities: mbeu yangu yamera isina kuremara (my seed has germinated well).

As Gwaravanda and Masaka $(2008,197)$ maintain, the Shona closely observe a relevant similarity between the clue to a given riddle and the answer to the riddle. This kind of observation cannot obtain without invoking rational powers to arrive at the solution of the riddle. To make use of analogical reasoning in the context of riddles, the Shona reflect on both similarities and differences and discern how relevant they are in arriving at the solution to the riddle (Gwaravanda and Masaka 2008, 197).

Based on the considerations above, it is evident that reason is characteristic of ethno-philosophy. In fact, as Ramose $(1999,42)$ observes, "there is no ontological defect among indigenous African people by virtue of which they may be excluded from the membership of Homo sapiens." If this is granted, it follows that Africans who have, for years, defended ethnophilosophy are justified in maintaining that it is a genuine philosophy. Thus claims by Hountondji and Appiah that ethno-philosophy is not based on reason and evidence cannot be justified.

The claim by Hountondji $(1996,56)$ that philosophy must have the same themes and must ask the same questions across cultures cannot go unchallenged. The questions to be asked are entirely determined by a people's existential circumstances, their world view as well as their geographical location. These factors cannot be the same across cultures. For instance, the fact 
that Africa is currently facing the challenges that have to do with ethnic conflicts, disease and economic disorder means that Africa is grappling with questions that relate to these particular challenges, and these questions are probably not being asked in Europe and North America, for example. Consequently, to dismiss ethno-philosophy on the basis that it has a different sort of questions to ask as compared to those questions that Western philosophy is currently asking will be grossly inappropriate.

Since most African countries were once colonies of Europe, and since the European colonisers, to a large extent, are responsible for the decimation of African cultures through their policies of assimilation and adoption, Africa needs to be united in order to embrace its own philosophy which is none other than ethno-philosophy. While the opportunities, experiences and challenges of each country may be different depending on who colonized them and the resources they possess, the facts of wars, hunger, diseases and religious imperialism ${ }^{5}$ are common across Africa, and ought to constitute the source of the unanimity.

Thus unanimity has to do with the acceptance by African nation-states that they have serious challenges emanating from their colonial past, and the project of ethno-philosophy is meant to find solutions to these challenges. Thus unanimity cannot be a myth and cannot be imaginary as Hountondji and Appiah would have us believe- since it is based on the African people's existential experiences and realities. There have been wars, poverty, hunger and diseases in South Sudan, Somalia, the Democratic Republic of Congo, Mali and Ivory Coast in recent years, and these problems have moved African countries to work together in search of solutions. Countries such as Zimbabwe, South Africa and Mozambique have sent peace-keeping missions to these troubled spots as a sign of solidarity, a gesture that is in keeping with the philosophy of ubuntu which says: "there is no way an individual can be healthy when the community is sick" (Yamamoto 1997, 52). This can be rephrased to read: "there is no way one African country can be peaceful when other African countries have wars." Thus to suggest, as Appiah $(1992,26)$ does, that "Africans share too many problems to be distracted by a bogus basis for solidarity" is to miss the point altogether.

The things that matter in Africa are unity, peace, shelter, health, education and food, among others. When it comes to these things, Africans of black extraction are really united. Appiah also runs the risk of hasty generalisation when he argues that Africans do not share things such as common language (Appiah 1992, 26). The Bantu people, who Tempels wrote about in his classic

\footnotetext{
${ }^{5}$ By religious imperialism, I mean the demonization of indigenous religions by the imperialists in order to promote the spread of foreign religions such as Christianity, Islam and others.
} 
book, Bantu Philosophy, are united by the Bantu language which is found in Southern and Eastern Africa that include countries such as Zimbabwe, South Africa, Lesotho, Swaziland, Botswana, Zambia, Malawi, Tanzania, Uganda, Kenya and Rwanda. The languages may not explicitly be the same, but they have a lot in common. For example, in Zimbabwe a person is called munhu/umuntu; in South Africa the word is umuntu and in Botswana the word is muthu.

Appiah's assertion that African societies have much in common with traditional societies that are not African as they do with each other is, to me, a claim which cannot be validated. In fact, African societies have a lot of things in common, one of which is the idea of community and peaceful co-existence. This idea runs across almost all African societies, although it is known by different names. In Southern Africa it is known as hunhu/ubuntu/botho, while in some Western African countries such as Ghana it is known as okra; and among the Igbo of Nigeria it is called umunna (Egwutuorah 2013, 411; Mangena 2015, 7). The idea is that community interests come before individual ones. What this means is that the achievements of the individual are only important if they lead to the betterment of the community as a whole (cf. Ramose 1999; Mangena 2012a; Mangena 2012b; Gade 2011). Thus the Shona people of Zimbabwe say munhu munhu muvanhu; in isiNdebele and Zulu language of Zimbabwe and South Africa respectively they say umuntu ngumuntu ngabantu, and both sayings translate into English as "a person is a person through other persons" (cf. Mangena 2012a; Mangena 2012b; Shutte 2008; Tutu 1999).

\section{Conclusion}

In this article, I have argued for the need to respect ethno-philosophy as an authentic philosophy at the same level with British philosophy, American philosophy, and Greek philosophy, to name a few of the so-called genuine philosophies of the world. Citing examples from Zimbabwe and Nigeria, I have sought to illustrate, through the use of proverbs and riddles, that ethnophilosophy is based on reason and evidence. I have argued that it was grossly unfair for professional African philosophers such as Hountondji and Appiah to treat ethno-philosophy as merely a collection of beliefs, customs, values and traditions of a people. I am convinced that in the process, I have succeeded in replying to my critics - old and new - with regard to the need to treat ethno-philosophy with utmost respect. 


\section{References}

Anyanwu, K.C. and E.A. Ruch. 1981. African Philosophy: An Introduction to the main philosophical trends in Contemporary Africa. Rome: Catholic Book Agency.

Appiah, K.A. 1992. In My Father's House: Africa in the Philosophy of Culture. New York: Oxford University Press.

Ciaffa, J.A. 2008. "Tradition and Modernity in Post-colonial African Philosophy". Humanitas, Vol. XX1 No. 1\&2, pp. 121-145.

Emagalit, Z. 2006. "Contemporary African Philosophy". http://faculty.msmc.edu/lindeman/af.html\#Ethnophilosophy

English, P. and K.M. Kalumba. 1996. African Philosophy: A Classical Approach. New Jersey: Prentice-Hall.

Gade, C.B. 2011. "The Historical Development of the Written Discourses on Ubuntu". South African Journal of Philosophy, Vol.30 No. 3, September 2011, pp. 303-330.

Groarke, L.F. 2014. "Deductive and Inductive Arguments". Internet Encyclopedia of Philosophy. http://www.iep.utm.edu/ded-ind/ Accessed 25 August 2014.

Gwaravanda, E.T. and D. Masaka. 2008. "Shona Reasoning Skills: The Importance of Riddles". Journal of Pan-African Studies, Vol. 2 No. 5, pp. 193-208.

Hegel, G.W.F. 1956. The Philosophy of History. J. Sibree trans. New York: Dover Publications.

Horner, C and E. Westacott. 2000. Thinking through Philosophy: An Introduction. New York: Cambridge University Press.

Hountondji, P.J. 1996. African Philosophy: Myth and Reality, Second Edition. London: Hutchinson and Company Publishers Ltd.

Imbo, S.O. 1998. An Introduction to African Philosophy. Lanham, Maryland: Rowman and Littlefield Publishers.

Janz, B.B. 2009. Philosophy in an African Place. Plymouth: Lexington Books.

King, P.J. 2007. "Introduction”. African philosophy. http://users.ox.ac.uk/ shil0124/africanphilosophy.html

Levy-Bruhl, L. 1995. "How Natives Think". In A. Mosley ed. African Philosophy: Selected Readings. New York: Prentice-Hall.

Maduka, E. 2005. "David Hume's ‘On National Character'”. In James N Elogbo et. al. eds. Racism, Philosophy and African Thought. http://www.frasouzu.com/issues\%20and20\%papers/Enyimba\%20

Mangena, F. 2012a. On Ubuntu and Retributive Punishment in Korekore-Nyombwe Culture: Emerging Ethical Perspectives. Harare: Best Practices Books.

--. 2012b. "Towards a Hunhu/Ubuntu Dialogical Moral Theory". Phronimon: Journal of the South African Society for Greek Philosophy and the Humanities, Vol. 13 No. 2, pp. 1-17.

--. 2015. "Restorative Justice's Deep Roots in Africa”. South African Journal of Philosophy, Vol. 34 No.1, pp. 1-12. 
Offia, E. 2009. “The Problem of Rationality in the History of African Philosophy". http://ezinearticles.com/?The-Problem-of-Rationality-in-the-History-of-AfricanPhilosophy\&id=2992308

Onyewuenyi, I. 1991. "Is there an African Philosophy?" In T. Serequeberhan ed. African Philosophy: The Essential Readings. New York: Paragon House.

--. 1994. The African Origin of Greek Philosophy: An Exercise in Afrocentrism. Nsukka: University of Nigeria Press.

Oyeshile, O.A. 2008. "On Defining African Philosophy: History, Challenges and Perspectives". Humanities and Social Sciences Journal, Vol. 3 No. 1, pp. 57-64.

Ozumba, G.O. 2014. Njikoka Amaka: Further Discussion on the Philosophy of Integrative Humanism. Calabar: $3^{\text {rd }}$ Logic Option Publishing.

Ramose, M.B. 1999. African Philosophy through Ubuntu. Harare: Mond Books.

Senghor, L. 1995. "On Negrohood: Psychology of the African Negro”. In A. Mosley ed. African Philosophy: Selected Readings. New York: Prentice-Hall.

Shutte, A. 2008. "African Ethics in a Globalizing World”. In R. Nicolson ed. Persons in Community: African Ethics in a Global Culture. Scottsville: University of KwaZuluNatal Press, pp. 15-34.

Towa, M. 1971. Essai Sur la problematique philosophique dans l' Afrique actuelle. Yaounde: CLE.

Tutu, D. 1999. No Future without Forgiveness. New York: Doubleday.

Wiredu, K. 1979. "How Not to Compare African Thought with Western Thought". In Richard Wright ed. African Philosophy: An Introduction. Washington, D.C.: University Press of America.

Yamamoto, E.K. 1997. "Race Apologies”. Journal of Gender, Race and Justice, Vol. 1, pp. 4788. 